\title{
THE MALVERN FAULT
}

SIR,-Many years ago, when visiting Great Malvern under the guidance of a local geologist, whose name I am sorry to have forgotten, I was shown a temporary exposure in the rear of the westernmost row of buildings. This showed a very steep face of Archaean, with remains of a plastering of what appeared to be Bunter sandstone. The obvious interpretation was that here was a fault-plane, the first of a series of steps leading down to the Keuper marl below. The references to Murchison given by Mr. Falcon (ante, p. 236) are consistent with this observation and interpretation.

For the sentence of mine quoted by Mr. Falcon (footnote, p. 229), I must offer belated apologies. It was written at a time when my field experience of the Malvern area was almost nil.

\section{A. Morley Davies.}

\section{AMERSHAM,}

BuCKs.

23rd Aug., 1947.

\section{THE MYNACHDY GNEISS}

SIR,--In the Anglesey Memoir (p. 296) orthoclase is said to be found in the gneisses of Mynachdy. During my revision of the Blake Collection, I made a re-study of this slide (E. 10643), and found in it no orthoclase. A negative felspar there certainly is, but its refractive index differs but little from that of quartz.

The interest is much more than local, for this is the only remaining exception. We now can say with confidence that in unequivocal gneisses no orthoclase has ever been found.

AEthiwy RiDGe,

EDWARD GreENLY.

BANGOR.

2nd July, 1947. 